\title{
Attitude towards Online Advergame: An Empirical Study among Saudi Consumers
}

\author{
Dr. Soad A. Al-Meshal \\ Assistant Professor \\ Marketing Department \\ College of Business Administration \\ King Saud University \\ Riyadh, Saudi Arabia
}

\begin{abstract}
As a result of the increase of computer games and high speed internet connections, in-gameadvertising playsasignificant role in this domain.Advertisers'anticipatethat in-gameadvertisingwill be an important marketing methodthat may enable themto reachtargetedconsumers.Consumers' attitudes toward in-game advertising, how consumers think about online advertising and the impact of these attitudes on brand image will be investigated in this study. In order to test the attitudes, several factors such as entertainment, customer engagement, andattitude toward advergames in general are included. The outcomesand results will be discussed at the end of this study. Discussion, implications, conclusion, limitations and future studies areto be provided.
\end{abstract}

Keywords: In-game advertising, Brand image, online advergames, Consumer engagement, Entertainment.

\section{Introduction}

In fact marketers and manufacturers have applied new form of ads to gain consumer acceptance.In-game advertisement was new trend that attracted companies to place products. Recently, the game industry has become an attractive and significant tool in the global marketplace(Yang, 2006).This encouragesmany companies to adoptadvergames as a part of the marketing methods.

Nevertheless, research in advergames are more recent and still limited (Kinard and Hartman, 2013). Studies in advergames have discussedadvergames content (An and Kang, 2014; Lee et al., 2009; Moore, 2006; Paeket al., 2014; Quilliamet al., 2011). Less attention has been given to investigate the effect of attitudes towards advergames to brand image.

This studyaims to shed light on the in-gameadvertising and investigate the relationshipsamongvarious variables (brand image, entertainment and customer engagement). Moreover, marketers have decided to enter the in-games advertisement area(Hsu \& Lu, 2004). Accordingly, this paper intends to better understanding ofthe games using and what the practitioners' attitudes are towardonline advertising and advergames particularly.

\section{Research Problem Statement}

The current study aims is to examine the relationships between the attitude towards online in-game advertising and brand image, entertainment and customer engagementamong Saudi context.

\section{Research Objectives}

The research aims to:

- Illustrate the impact of attitudes toward the advergames on brand image.

- Explain the influence of customer engagement as a mediating onthe attitude toward both advergames and brand image.

- Clarify the mediating effect of entertainment on the attitude toward both advergames and brand image.

- Figure out the relationship type between attitudes toward advergamesand the study variables.

\section{Research Questions}

- To what extent do the attitudes towards advergames affect brand image?

- How does the level of entertainment influence the attitude toward advergames?

- How does the level of customer engagement influence the attitude toward advergames?

- Do attitudes toward the advergames affectedby customer engagement and entertainment? 


\section{Significance of the Study}

The in-game advertising becomes an interesting choice for companies to place products in. Both marketers and producers advergamesare creative and innovative channel to communicate with their potential audience. This paper will take the subject of the evolution of rapidly growing industries and establishment of competitive advantages. The study will contribute also by deeply investigate the game players' attitudes towards in-game advertising.

\section{Literature Review}

The gaming industry has become a significant revenue generator in the entertainment business(Kent, 2001).Historically, the first video game was introduced in 1950(Kent, 2001). It is expected that the video game industry will maintain its fast growth (Lai \& Huang, 2011).In this section,the literature will be reviewed in the aspects of ingame advertising, attitude toward advergames, brandimage, entertainmentand relevance.

\section{In-game Advertising}

A new way of advertising is to deliversthe advertisement messagesthroughvideo or computer game. The major goal is to provide a means to virtually interact with products and increase the brand awareness(Hernandez and Minor, 2015).

This form of advertising iscalled in-game advertising(IGA).Digital In-game advertising (DIGA)consists of two different types of in-game advertising used in games. Practically, the dynamic placement is the advanced type of ingame advertising. It works by an Internet connection that helps marketers insert any changes at any time to the advertisement into the game (Nelson, 2002).

In-game advertising is divided into two distinct categories: advergames and brand integration. Usually, online advertising is much concernedwith both meta-categories. Thus, the definitions of the two categories and how they are used online will be elaborated below in details.

Advergames, in definition, is one form of Internet advertising which combines two aspects together. This type of advertising seeks to promote products by placing the advertising in online games (Grossman, 2005). It is a combination of a commercial message and a game used for the sake of product promotion purposes. Moreover, the unique advantage of advergames is that it makes the consumers communicate with the product in an interesting, enjoyable and interactive way. Advergames enhance brand awareness and long term relationship between the consumer and the product(Nielsen et al., 2004).

Vanhala et al. (2015)studied the peculiarity of computer game organizations and their human resources.They observed that one or more developers and the core team are formed over a game designer, partners and outsourcing changes.More than that, in advergames the use of language is minimized. A unique environment is offered in advergames for Internet audiences (Hernandez and Minor, 2015).

\section{Attitudes towardOnline Advergames}

Online advergames is a new technique used by marketers to enrich advertising messages (Gould and Gupta, 2006).An attitude toward advergames is defined as: "an affective construct assessing favorable or unfavorable consumer predisposition toward the advergames itself resulting from active user/game interaction" (Hernandez et al., 2004).

Nelson's (2002) was the first study found on product placement in-gameswhich explored the use of digital games context to place the products in it. The study investigated the consumers' feeling about game placementand found that consumers accepted the products and had a general positive attitude toward placement in games.

Additionally, some studies found positive relationship between attitudes toward advertising in general and placement in games was confirmed. More than that, these studies found that people who have negative attitudes toward advertising will have negative attitudes toward product placement using games (Hernandez et al., 2004; Winkler \& Buckner, 2006; Yang, M. et al., 2006).

From the cognitive learning point of view, attitudes are the results of information evaluation to any object. The conceptual model of attitudes illustrated that attitudes are the sum of evaluation of the beliefs toward an object. Using cognitive theory to interpret the attitudes has its benefits like reducing the ambiguity and gaining the knowledge but on the other hand it is time consuming. Therefore, consumers are often unwilling to participate in mental activities that may weaken the message`s content (Garbarino\&Edell, 1997; Lai \& Huang, 2011; Stoughton, 2005).

Another studies figured out that consumers enjoy attracting new media especially for hedonic purposes. Games offer a kind of learning processes. It enhances the experience by continuous repetition to the favorable attitudes. The involvement in games can make consumers believe the stated message with classical condition exposuresand affect consumers recall, attitudes and other brand outcomes (Folkvord et al., 2015; Stanley, 2006; Verolien\& De Pelsmacker, 2010). 


\section{Brand Image}

Brand image was defined by Keller (1993) as "perceptions about a brand as reflected by the brand associations held in consumer memory". Also, brand image is the key driver of brand attitude, brand acceptance and brand equity. Therefore, the main purpose of marketing activities is to influence consumers' attitude towarda brand to establish the brand image in consumers' mind.

The attractive trends towards interactive and brand-centered using advergames were found as immersive opportunities that can strengthen brand images, studies confirmed that heavy gamers memory were found more significant compared to infrequent players (Mallinckrodt and Mizerski, 2007; Yang et al., 2006).

On the other hand, contradictory results showed some differences among video game between experts and non-gamers experience and level of recall among (Boot et al. 2008; Chaney et al., 2004).

\section{Entertainment}

According to the Entertainment Marketing Association (2004), all types of brand placements such as TV, movies and in-game advertising share some similarities. All these types are marketing communication methods used tobuild brand equity,awareness and alsoincrease profits.In fact, another similarity between the previous types is the entertainment factor. While they arewatching TV or playing a game, consumers enjoy watching brands(Chen \& Wells, 1999).

Entertainment is the ability to fulfill the audience`s need of entertainment, escapism and diversion. It has the ability to enhance online consumers' experience.In addition, it is the main communication exchange driver in gratifications research. According to Lee (2009), perceived enjoyment and interaction may affect people's intention to play online games. This study was an extension for the TPB to predict how prior experience and perceived enjoyment explain the intention to play online games. A proposed model based on the technology acceptance model (TAM) was developed to examine the perceived enjoyment. Therefore, the proposed model shows that the players have enjoyment reasons and high intention to play interactive online games. Found by (Ferrazzi et al., 2003; Gao, 2004), there is a positive correlation between entertainment and attitudes toward online advertising.

\section{Customer Engagement}

Consumer engagement is an essential factorin recent marketing literature.Consumer engagement offers a base of customer relationship marketing (Fournier, 1998). Thus consumer engagement will add value by supporting the increasingcustomer interactive and the nature of consumer relationships (Laurence et al., 2015; Vivek Beatty and Morgan, 2012). They define it as "the intensity of an individual's participation in and connection with an organization's offerings or organizational activities, which either the customer or the organization initiates".Consumer engagement has been defined as "a psychological state that occurs through interactive, co-creative consumer experiences with a focal agent/object" (Brodie et al., 2011a, p. 2).More than that, engaging consumers beyond core purchase situations they will exhibit different roles and behave with the value co-creation logic (Vargo and Lusch,2004). Recently, consumer engagement isbecoming one of the key objectives of marketing.Positive implications were recorded of consumer engagement for brand performance (Brodieet al., 2011a, 2011b).However, the literature on consumer engagement shows that customerengagement is critical in network governing service relationships. It is a multidimensional concept that expresses relevant cognitive, emotional and/or behavioral dimensions (Ingrid, 2015; Velitchka et al., 2014).

\section{Research Model}

This study was based on the following proposed model:

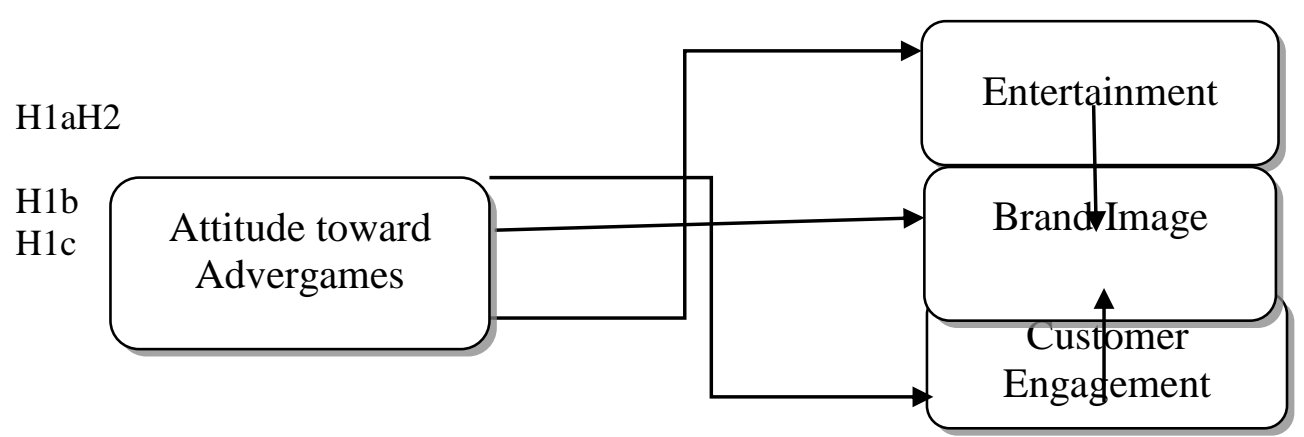

Figure 1: Proposed Model 


\section{Research Hypotheses}

H1a:There is a positive and significant relationship between attitudes toward advergames and entertainment

H1b: There is a positive and significant relationship between attitudes toward advergames and brand image

H1c: There is a positive and significant relationship between attitudes toward advergamesand customer engagement

H2: There is a positive and significant relationship between entertainment and brand image

H3: There is a positive and significant relationship between customer engagement and brand image.

\section{Methodology}

\section{Sampling Frame and Data Collection}

Data for this study was collected via a survey. The sample was from diversity of consumers with different ages, gender, educations, and occupations in Saudi context. Surveys were administer to participants by email. Participants were informed with the purpose of the research. Participants were informed that their responses would remain confidential. No monetary incentive was provided. A number of 200 questionnaire were distributed, the valid questionnaires were 143 which used in the analysis. Thus, the response rate is $71.5 \%$.

\section{Scale development and measurements}

To commence the measurement process, the scales used in this study have been sourced from literature. Then, entertainment was measured by seven-item modified scale proposed by Leung (2003). Attitudes toward advergames were measured by four additional items adapted from Hernandez et al. (2004). Brand image is measured by an eightitem scale, which is adopted by Salinas and Jose (2009).Customer engagement was measured by nine items adopted from social engagement scale.Demographic variables were added in separate part of the questionnaire.

\section{Measure validation}

Statistical procedures were taken to validate the measures included assessments of reliability as well as content validity. Pilot study was conducted to measure the modified scale as well. Several statistical techniques were used in this paper in order to test the data. Regression analysis and Analysis of variance (ANOVA) were be used to examine the relationship between the independent variables and to figure out the hypothesized relationships.

\section{Data Analysis}

\section{Reliability Analysis}

In order to ensure the reliability of the study tool, we used internal consistency reliability through Cronbach's alpha test. According to table (1) the overall reliability value is (0.93) which is an acceptable level of reliability.

Table (1) Cronbach's alpha value

\begin{tabular}{|c|c|}
\hline Variables & Cronbach's alpha value \\
\hline Attitude towards Advergames & 0.79 \\
\hline Entertainment & 0.75 \\
\hline Customer Engagement & 0.78 \\
\hline Brand Image & 0.81 \\
\hline Total & 0.83 \\
\hline
\end{tabular}

\section{Statistical Analysis}

The main objective of the study was to explore the Attitude towards advertising in online games. In order to achieve the objective and come up with result, the study based on calculated means for questionnaire items which built according to Likert scale as following:

1. 1 to 1.80 strongly disagree, which means that does not affect.

2. 1.81 to 2.60 disagree, which means there is a weak effect.

3. 2.61 to 3.40 neutral, which means there is Median effect.

4. 3.41 to 4.20 agree, which means there is a significant impact somewhat.

5. 4.21 to 5 strongly agree, which means there is a huge impact.

The standard deviations and mean level for each questionnaire item. The results showed that the mean scores were range from $2.50-3.26$ and the standard divinations were between (1.02- 2.45).Accordingly, the most items in the domain of median level. 
Table (2): Means and Std.Deviation for Questionnaire dimension

\begin{tabular}{|c|c|c|c|}
\hline & Mean & $\begin{array}{c}\text { Std. } \\
\text { Deviation }\end{array}$ & $\begin{array}{c}\text { Mean } \\
\text { Level }\end{array}$ \\
\hline Attitude towards Advergames & 2.67 & 0.89 & Median \\
\hline Entertainment & 2.71 & 0.90 & Median \\
\hline Customer Engagement & 2.78 & 0.91 & Median \\
\hline Brand Image & 3.02 & 0.85 & Median \\
\hline
\end{tabular}

Table (2) represent that the mean and Std. Deviation for research dimension. The means for all dimension is median mean level, whereas the highest mean level is for brand image dimension.

\section{Hypotheses Testing}

H1a,b,d: There is a positive and significant relationship between attitudes toward advergames and (brand image, entertainment and customer engagement).

In order to test this hypothesis, Pearson correlation test was used as follow:

Table (3): correlation test for hypothesis 1

\begin{tabular}{|c|c|c|c|c|}
\hline \multicolumn{2}{|c|}{} & Entertainment & $\begin{array}{c}\text { Customer } \\
\text { Engagement }\end{array}$ & Brand Image \\
\hline \multirow{2}{*}{$\begin{array}{c}\text { Attitude } \\
\text { towards } \\
\text { Advergames }\end{array}$} & Pearson correlation & 0.62 & 0.48 & 0.52 \\
\cline { 2 - 5 } & $\mathbf{S i g}$ & 0.00 & 0.00 & 0.00 \\
\hline
\end{tabular}

According to table (3), it is present the correlation between (Entertainment, Customer Engagement and Brand Image) and Attitude towards Advergames. Based on result there is a median positive relation between these factors. As well as the highest relation is between Attitude towards Advergames and Entertainment. So we can accept the alternative hypothesis which state "There is a positive and significant relationship between attitudes toward advergames and (brand image, entertainment and customer engagement)".

H2: There is a positive and significant relationship between entertainment and brand image.

In order to test this hypothesis, Pearson correlation test was used as follow:

Table (4): correlation test for hypothesis 2

\begin{tabular}{|c|c|c|}
\hline \multirow{2}{*}{} & Brand Image \\
\hline \multirow{2}{*}{ Entertainment } & Pearson correlation & 0.49 \\
\cline { 2 - 3 } & Sig & 0.00 \\
\cline { 2 - 3 } & $\mathbf{N}$ & 143 \\
\hline
\end{tabular}

Table (4) showed that the relationship between Entertainment and Brand Image. Pearson correlation value between these factors are (0.49) which indicate to median positive relation with significant level less than 0.05 . Accordingly, we accept the hypothesis.

H3: There is a positive and significant relationship between customer engagement and brand image In order to test this hypothesis, Pearson correlation test was used as follow:

Table (5): correlation test for hypothesis 3

\begin{tabular}{|c|c|c|}
\hline \multicolumn{2}{|c|}{} & Brand Image \\
\hline \multirow{2}{*}{$\begin{array}{c}\text { Customer } \\
\text { Engagement }\end{array}$} & Pearson correlation & 0.52 \\
\cline { 2 - 3 } & Sig & 0.00 \\
\cline { 2 - 3 } & $\mathbf{N}$ & 143 \\
\hline
\end{tabular}

Table (5) showed that the relationship between Customer Engagement and Brand Image. Pearson correlation value between these factors are (0.52) which indicate to median positive relation with significant level less than 0.05. Accordingly, we accept the hypothesis that state there is a positive and significant relationship between customer engagement and brand image. 
Table (6): Hypotheses Results

\begin{tabular}{|c|c|c|}
\hline Variables & Sig. & Result \\
\hline Attitude towards Advergames & 0.00 & Supported \\
\hline Entertainment & 0.00 & Supported \\
\hline Customer Engagement & 0.00 & Supported \\
\hline Brand Image & 0.00 & Supported \\
\hline
\end{tabular}

Table (6) shows the results of all hypotheses testing, they all are supported.

\section{Findings and conclusion}

The analysis results shows positive relationships between all the assigned hypotheses. Accordingly, there is a positive and significant relationship between attitudes toward advergames and (brand image, entertainment and customer engagement). This supported the previous studies findings which found high association between the attitude and ingame ads (Ferrazzi et al., 2003; Folkvord et al., 2015; Gao, 2004; Stanley, 2006; Verolien \& De Pelsmacker, 2010). The study confirmed the positive relationship between both entertainment and customer engagement with brand image in the Saudi context. This study concluded that it is acceptable by consumers to have ads in-games which has a positive image and encourage customer engagement.

\section{Limitation}

The study certain limitations, first, not all the online games have ads. Second, most of those who play games are young people which may have different mentality than eldest people.

\section{Future Studies}

For future studies it is advisable to replicate this study from the organization perspective. Replication in other context is needed for generalization. Furthermore, the online in games advertising may be studied in comparison with the traditional advertising tools.

\section{Acknowledgement}

This is a research paper that was supported by a grant from the Research Center for the Humanities, Deanship of Scientific Research at King Saud University.

\section{References}

An, S. and Kang, H. (2014). Advertising or games? Advergames on the internet gaming sites targeting children.International Journal of Advertising, 33(3), 509-532.

Boot, W.; Kramer, A.; Simons, D.; Fabiani, M., and Gratton, G. (2008). The effects of video game playing on attention, memory, and executive control. Acta Psychologica, 29(3), 387-398.

Brodie, J.R., Hollebeek, L., Juric, B. and Ilic, A. (2011a). Consumer engagement: conceptual domain, fundamental propositions and implications for research. Journal of Service Research, 14(3), 252-271.

Chaney, J., Lin, K.-H., and Chaney, M.I.(2004).The effects of billboards within the gaming environment. Journal of Interactive Advertising, 4(3), 1-47.

Chen, Q., and Wells, W.D.(1999).Attitude toward the site. Journal of Advertising research, 39(5), 27-38.

Gould, S.J. and Gupta, P.B. (2006). Come on down: how consumers view game shows and the products placed in them. Journal of Advertising, 35(1), 65-81.

Ferrazzi, K., Chen, J., \& Li, Z.(2003). Idea: playing games with customers. Harvard Business Review, 81, 21.

Folkvord, F., Anschutz, D.J., Wiers, R.W. and Buijzen, M. (2015). The role of attentional bias in the effect of food advertising on actual food intake among children. Appetite, 84(1), 251-258.

Garbarino, E. C., and Edell, J. A.(1997).Cognitive effort, affect, and choice. Journal of Consumer Research, 24, 147159.

Fournier, S. (1998).Consumers and Their Brands: Developing Relationship Theory in Consumer Research. Journal of Consumer Research, 24, 343-373.

Gao, Y. (2004).Appeal of online computer games: a user perspective. The Electronic Library, 22 (1), 74-8.

Grossman, S.(2005).Grand Theft Oreo: The constitutionality of advergames regulation.Yale Law Journal, 115(1), 227236.

Hernandez, M.D., Chapa, S., Minor, M.S., Maldonado, C., and Barranzuela, F.(2004). Hispanic attitudes toward advergames: a proposed model of their antecedents. Journal of Interactive Advertising, 5(1), 1-75. 
Hernandez, M and Minor, M. (2015). False recall of brands in advergames: a cross-country comparison. Journal of Research in Interactive Marketing, 9(1), 54 - 69.

Hsu, C., and Lu, H. (2004). Why do people play on-line games?An extended TAM with social influences and flow experience. Information and Management, 41(7), 853-68.

Ingrid M. O'Brien Wade Jarvis Geoffrey N. Soutar (2015). Integrating social issues and customer engagement to drive loyalty in a service organization,Journal of Services Marketing, 29 (6/7), 547 - 559.

Keller, K. L. (1993). Conceptualizing, Measuring, and Managing Customer-Based Brand Equity.Journal of Marketing Research, 29: 1-22.

Kinard, B.R. and Hartman, K.B. (2013). Are you entertained? The impact of brand integration and brand experience in television-related advergames. Journal of Advertising, 42 (2/3), 196-203.

Lai, M., and Huang, Y.(2011). Can Learning theoretical approaches illuminate the ways in which advertising games effect attitude, recall, and purchase intention. International Journal of Electronic Business Management, 9(4), 368-380.

Lee, M.(2009).Understanding the behavioral intention to play online games An extension of the theory of planned Behavior. Online Information Review, 33(5), 849-872.

Lee, S.Y. and Shen, F. (2009). Joint advertising and brand congruity: effects on memory andattitudes.Journal of Promotion Management, 15(4), 484-498.

Leung, L. (2003).Impacts of net-generation attributes, seductive properties of the internet, and gratifications-obtained on internet use. Telemetric and Informatics, 20(2), 107-29.

Laurence, D.; Cleopatra, V.; and Anna, T. (2015). Consumer engagement in online brand communities: a social media perspective.Journal of Product \& Brand Management, 24(1),28 -42.

Mallinckrodt, V. and Mizerski, D. (2007). The effects of playing an advergame on young children's perceptions, preferences, and requests.Journal of Advertising, 36(2), 87-100.

Mehta,A.(2000).Advertising attitudes and advertising effectiveness. Journal of AdvertisingResearch, 40(3), 67-72.

Moore, E.S. (2006), It's Child's Play: Advergaming and the Online Marketing of Food to Children, Kaiser Family Foundation, Menlo Park, CA.

Nielson, R., Keum, H. and Yaros R.A. (2004).Advertainment or Adcreep: Game Player's Attitudes toward Advertising and Product Placements in Computer Games. Journal of Interactive Advertising, 5(1), 3-30.

Nelson, M.(2002). Recall of Brand Placement in Computer/Video games. Journal of Advertising Research,42(2), 8092.

Paek, H.-J., Quillium, E.T., Kim, S., Weatherspoon, L.J., Rifon, N.J. and Lee, M. (2014). Characteristics of food advergames that reach children and the nutrient quality of the foods they advertise.Internet Research, 24(1), 63-81.

Quilliam, E.T., Lee, M., Cole, R.T. and Kim, M. (2011). The impetus for (and limited power of)business selfregulation: the example of advergames. Journal of Consumer Affairs, 45(2), 224-247.

Salinas, and Jose. (2009). Modeling the Brand Extensions' Influence on Brand Image. Journal of Business Research, $62,50-60$.

Stanley, T. (2006). Advergames, content role juice up marketer's game. Advertising Age, 77, 1-6.

Stoughton, S. (2005).Skittles taps advergaming for product ads. Marketing News, 39(34), 1-44.

Vanhala, E., kasurinen, J., and Smolander, K. (2015). Evolution of computer game developer Organizations, Journal of Advances in Management Research, 12(3), 268 - 291.

Vargo,S., and Lusch, R. (2004). Evolving to a New Dominant Logic for Marketing. Journal of Marketing, 68, 1-17.

Velitchka D.; Kaltcheva A.; Patino, M., Laric, D.; and Pitta, N. (2014). Customers' relational models as determinants of customer engagement value. Journal of Product \& Brand Management, 23(1), 55 - 61.

Verolien, C., and De Pelsmacker, P.( 2010).Advergames. Journal of Advertising, 39(1), 5-18.

Vivek, S.D., Beatty, S.E. and Morgan, R.M. (2012). Customer engagement: exploring customer relationships beyond purchase.The Journal of Marketing Theory andPractice, 20 (2), 122-146.

Winkler, T., and Buckner K. (2006).Receptiveness of Gamers to Embedded Brand Messages in Advergames: Attitudes towards Product placement. Journal of Interactive Advertising, 7(1), 37-46.

Yang, M.(2006).The Effectiveness of In-Game Advertising: Comparing College Students' Explicit and Implicit Memory for Brand Names. Journal of Advertising, 35(4), 143-155.

Yang, M., Roskos-Ewoldsen, D. R., Dinu, L., \&Arpan, L. M.( 2006).The effectiveness of in-game advertising: Comparing college students explicit and implicit memory for brand names. Journal of Advertising, 35(4), 143152. 